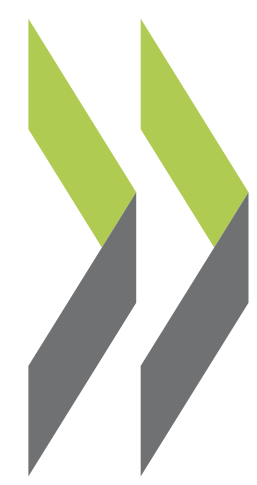

OECD Economics Department Working Papers No. 862

French Social Housing in an International Context
Kathleen Scanlon,

\author{
Christine Whitehead
}


Organisation de Coopération et de Développement Économiques

Organisation for Economic Co-operation and Development

12-May-2011

ECONOMICS DEPARTMENT

English - Or. English

FRENCH SOCIAL HOUSING IN AN INTERNATIONAL CONTEXT

ECONOMICS DEPARTMENT WORKINGS PAPERS No. 862

by Kathleen Scanlon and Christine Whitehead

All Economics Department Working Papers are available through the OECD internet website at www.oecd.org/eco/workingpapers

JT03301658

Document complet disponible sur OLIS dans son format d'origine

Complete document available on OLIS in its original format 


\section{ABSTRACT / RÉSUMÉ \\ French social housing in an international context}

In this paper we describe the main features of the French social housing system as viewed from abroad, and place it within the context of systems in other major developed countries, particularly in Europe. At $17 \%$ of the total stock the social sector in France is of similar scale to many other European countries but aims to play a more 'universalist' role. Moreover the sector still benefits from a special circuit of finance as well as direct subsidies to a greater degree than many comparator countries. Even so, increasing proportions of social tenants come from lower income groups and the government has legislated for rights to assistance. In this context we examine the comparative evidence on the stock of social housing and new construction in the sector; financing and subsidy regimes; systems for allocating tenants to social-housing dwellings; and the resulting demographics. We identify some French policies and practices that reflect the country's relative interest in maintaining a traditional social sector and areas such as public/private partnership where France has acted as leader in policy development. We also identify aspects of social housing where France is anomalous in a European context, as well as some where policy appears to have limited economic rationale. Finally, we make some observations about possible future policy directions. This Working Paper relates to the 2011 OECD Economic Survey of France (www.oecd.org/eco/surveys/france).

JEL classification codes: H42; H75; R21; R30; R31; R38.

Keywords: Comparative housing policy; French housing policy; housing subsidies; social housing.

$* * * * * * * * * * * * * * *$

\section{Le logement social français dans une perspective internationale}

Dans ce document de travail, nous décrivons les principales caractéristiques du système de logement social français, vu de l'étranger, et le plaçons dans le contexte des systèmes d'autres grands pays développés, en particulier en Europe. Avec 17\% du stock total de logements, le secteur social en France est d'une envergure similaire à celui de nombreux autres pays européens, mais vise à jouer un rôle plus «universaliste». En outre ce secteur bénéficie toujours d'un circuit spécial de financement ainsi que des subventions directes à un degré plus élevé que dans de nombreux pays comparables. Cependant, des proportions croissantes de locataires de logements sociaux viennent de groupes à faible revenu et le gouvernement a légiféré en faveur de droits à l'assistance. Dans ce contexte, nous examinons les données comparatives du stock de logements sociaux et des nouvelles constructions dans le secteur, les régimes de financement et de subvention, les systèmes d'attribution des logements sociaux, et la démographique en résultant. Nous identifions certains politiques et pratiques françaises qui reflètent l'intérêt relatif du pays dans le maintien d'un secteur social traditionnel et des domaines tels que le partenariat public / privé où la France a agi comme novatrice dans l'élaboration des politiques. Nous avons également identifié les aspects du logement social où la France se singularise dans un contexte européen, ainsi que d'autres où les politiques semblent avoir peu de logique économique. Enfin, nous faisons quelques observations concernant de possibles orientations futures. Ce Document de travail se rapporte à l'Étude économique de l'OCDE de la France 2011 (www.oecd.org/eco/etudes/france).

Classification JEL: H42; H75; R21; R30; R31; R38.

Mots clés: politique comparée du logement; politique française du logement; subventions au logement; logement social.

Copyright $\odot$ OECD, 2011. All rights reserved. Application for permission to reproduce or translate all, or part of, this material should be made to: Head of Publications Service, OECD, 2 rue André-Pascal, 75775 PARIS CEDEX 16, France. 


\section{TABLE OF CONTENTS}

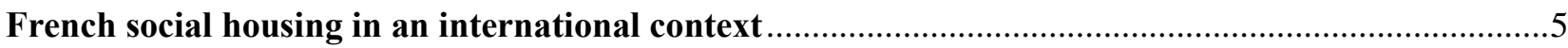

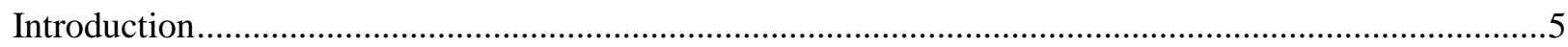

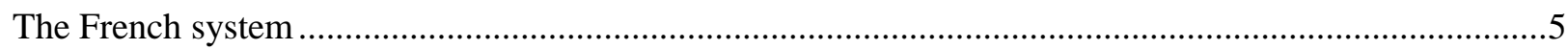

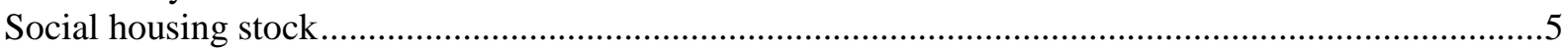

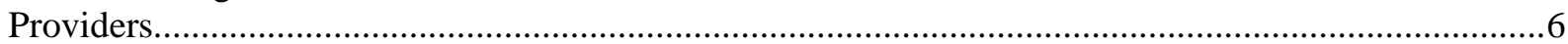

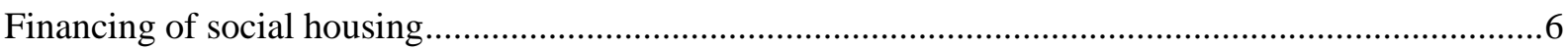

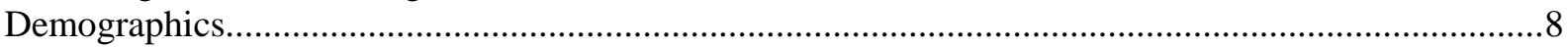

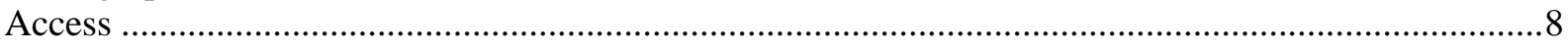

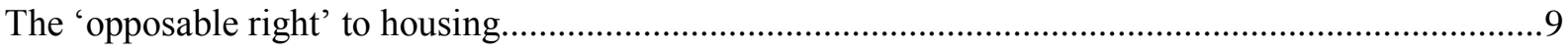

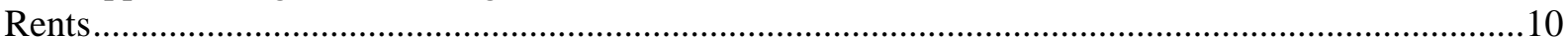

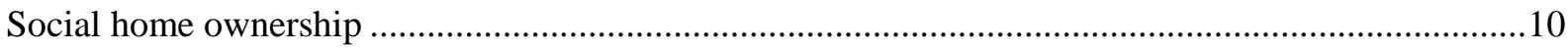

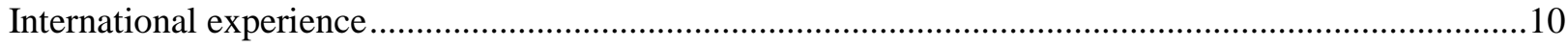

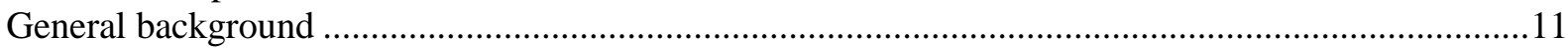

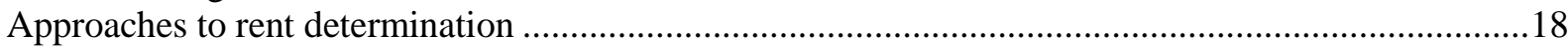

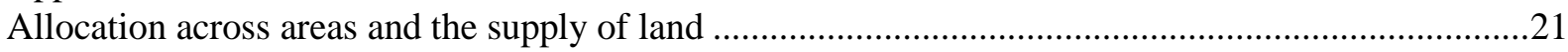

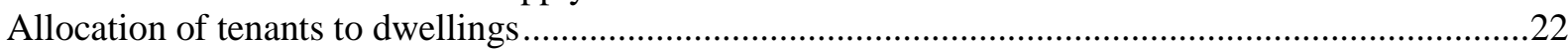

Demographics of social housing — where do the most vulnerable live? ............................................24

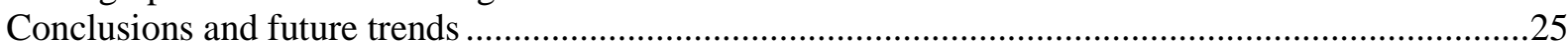

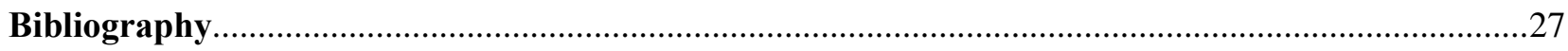

\section{Tables}

1. Off-market loans for social and intermediate housing in France .........................................................

2. Social rented housing as per cent of all housing, early 1990s, early 2000s and 2007 ........................11

3. Social housing as $\%$ of all housing completions, EU countries .........................................................13

4. Government policies to support supply of new social housing.........................................................15

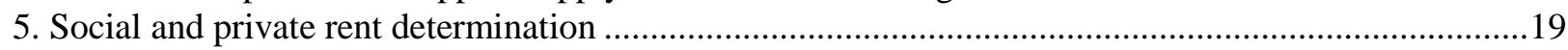

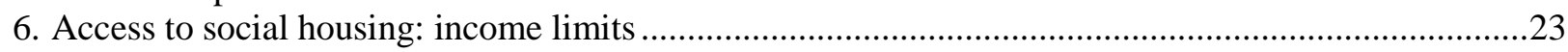

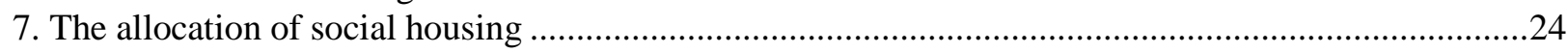

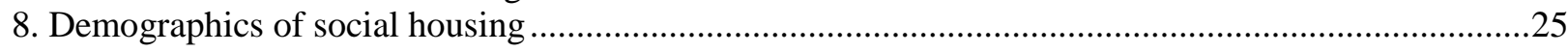


ECO/WKP(2011)31 
ECO/WKP(2011)31

\title{
FRENCH SOCIAL HOUSING IN AN INTERNATIONAL CONTEXT
}

\author{
By Kathleen Scanlon and Christine Whitehead ${ }^{1}$
}

\section{Introduction}

In this paper we describe the main features of the French social housing system as viewed from abroad, and place it within the context of systems in other major developed countries, particularly in Europe. We examine the stock of social housing and new construction in the sector, financing and subsidy regimes, systems for allocating tenants to social-housing dwellings and the resulting demographics. We identify some French policies and practices that are anomalous in a European context, as well as some for which there is perhaps only a limited economic rationale. Finally, we make some observations about possible future policy directions.

\section{The French system}

\section{Social housing stock}

In 2009 the French social rented sector had 4.5 million units, accounting for $17 \%$ of the country's housing stock. Some 55\% of the stock was built before 1976, including 1.12 million units built between 1966 and 1975, when many large estates were erected on the peripheries of France's cities. New construction was running at about 56000 units/year in the 1990s, but has since fallen below 50000 per year. Demolitions and sales mean that the annual net addition to the stock is about 40000 units/year. Around $86 \%$ of the existing units are flats - and in the Paris area this is 97\% (Levy-Vroelant and Tutin, 2007).

The distribution of social housing broadly reflects that of the French population. About $62 \%$ of social housing is located in towns or cities with more than 100000 inhabitants, but $14 \%$ is in small towns or rural areas. Within cities, however, there are major differences between the 'peripheral' stock, where estates are often dilapidated, and the more desirable central stock.

At the moment the distribution of social housing within metropolitan areas is very skewed. There are major concentrations in the banlieues around major cities such as Paris and Lyon (much of it in the now-notorious large housing estates of the 1960s and 1970s), while some prosperous communes have almost none.

Under Article 55 of the Solidarity and Urban Renewal Law (2000), known as the Loi SRU, at least $20 \%$ of the housing stock in all urban municipalities with over 3500 inhabitants should be social. The law states that those municipalities with a lower percentage of social housing are to draw up a plan for increasing their social stock, although its provisions also allow municipalities to pay a fine rather than do so; these fees are redistributed to municipalities with high proportions of social housing. This provision which has been much criticised by social-housing advocates for allowing well-off areas to escape their

1. This paper is part of a project related to the Economic Survey of France published in April 2011 under the authority of the Economics and Development Review Committee (EDRC). Kathleen Scanlon is a senior researcher at LSE London and Christine Whitehead is Professor in Housing in the Department of Economics at the London School of Economics. 
obligations, and many prosperous municipalities have so far resisted the government's efforts to make them increase their stock of social housing.

The national plan for urban renewal includes the demolition and re-development or rehabilitation of much social housing, with a goal of increasing social mix and attracting middle-class households. Social housing units that are demolished are often replaced with market housing, so displaced tenants must move to other areas.

\section{Providers}

Social housing is generally known as 'HLM housing' in France (HLM is an acronym for habitations à loyer modéré [moderate-rent housing]). About half of HLM housing is provided by public corporations established by local or regional authorities, known as les Offices publics de l'habitat or OPH. In 2008 there were $279 \mathrm{OPH}$ with about 2.1 million dwellings. Even though the $\mathrm{OPH}$ are locally based they are permitted to build and manage housing outside their own areas.

The other half is owned by private non-profit corporations (les Entreprises socials pour l'habitat $\mathrm{ESH}$ ), established by large companies with many employees (e.g. railways, the post office) or by financial groups or charities. In 2008 there were $281 \mathrm{ESH}$ with about 2 million dwellings (Driant, 2011).

\section{Financing of social housing}

Construction of new social housing is financed from several sources. In 2009 , about $71 \%$ of the cost of 'standard' new social housing under the PLUS scheme came from special loans (see below). Some 11\% came from the HLMs' own resources, about $13 \%$ from subsidies provided by local or regional governments, and the remainder from businesses through the $1 \%$ housing tax and from the State (Caisse des Depots, personal communication). In addition, new construction is subject to a reduced rate of VAT (5.5\% rather than the normal 19.6\%), which is effectively a further State subsidy. Fiscal subsidies have become more important in recent years, but interest-rate subsidies have fallen, mainly due to the current low level of market interest rates.

Dedicated long-term off-market loans are provided by a state-run financial institution, the Caisse des dépôts et consignations (Schaefer, 2003). The CDC, in turn, is funded by special tax-favoured savings deposits. HLMs are not obliged to borrow from the CDC; if they can borrow at better terms elsewhere they are free to do so. Employees also contribute through a 1\% 'housing tax' on wages, in return for which a certain percentage of social stock is set aside for them (see below).

There are three main types of social-housing loans available (Table 1), which fund housing aimed at three target groups. General housing for low-income households - 'standard' social housing - is funded by PLUS loans, which have a maximum term of 40 years (or 50 for land purchases) and come with a subsidy that covers between 12 and $18 \%$ of estimated costs, depending on the region and type of investment. 
Table 1. Off-market loans for social and intermediate housing in France

\begin{tabular}{|c|c|c|c|c|c|c|c|c|c|c|}
\hline \multirow{2}{*}{$\begin{array}{l}\text { Loan } \\
\text { type }\end{array}$} & \multirow{2}{*}{$\begin{array}{l}\text { Target } \\
\text { market }\end{array}$} & \multirow{2}{*}{$\begin{array}{c}\text { Per cent of } \\
\text { new social } \\
\text { housing } \\
2000-09\end{array}$} & \multirow{2}{*}{ Term } & \multicolumn{3}{|c|}{$\begin{array}{l}\text { Monthly real income limit for } \\
\text { family of } 3\end{array}$} & \multirow{2}{*}{$\begin{array}{l}\text { Rent } \\
\text { ceiling }\end{array}$} & \multirow{2}{*}{$\begin{array}{l}\text { Interest } \\
\text { rate }\end{array}$} & \multirow{2}{*}{$\begin{array}{l}\text { Other } \\
\text { concession }\end{array}$} & \multirow{2}{*}{ Notes } \\
\hline & & & & Paris & $\begin{array}{l}\text { Rest of lle } \\
\text { de France }\end{array}$ & Elsewhere & & & & \\
\hline PLUS & $\begin{array}{l}\text { Standard } \\
\text { social } \\
\text { housing }\end{array}$ & 60 & $\begin{array}{l}40 \text { years: } \\
50 \text { for land } \\
\text { purchase }\end{array}$ & $€ 4000$ & $€ 3600$ & $€ 2800$ & $\begin{array}{l}€ 4.73- \\
5.81 / \mathrm{m}^{2} \text { per } \\
\text { month, } \\
\text { depending on } \\
\text { location }\end{array}$ & $\mathrm{TLA}^{*}+0.60 \%$ & $\begin{array}{l}\text { VAT } 5.5 \% \\
\text { (normally } \\
19.6 \% \text { ); no } \\
\text { property tax for } \\
25 \text { years }\end{array}$ & $\begin{array}{l}\text { Associated subsidy of } 12 \text { to } 18 \% \text { of } \\
\text { costs }\end{array}$ \\
\hline PLA-I & $\begin{array}{l}\text { Lower- } \\
\text { income }\end{array}$ & 12 & As above & $€ 2400$ & $€ 2100$ & $€ 1700$ & $\begin{array}{l}€ 4.22 \text { to } \\
€ 5.49 / \mathrm{m}^{2}\end{array}$ & TLA $-0.20 \%$ & $\begin{array}{l}\text { VAT } 5.5 \% \text {; no } \\
\text { property tax for } \\
25 \text { years }\end{array}$ & $\begin{array}{l}\text { Associated subsidy of } 15 \text { to } 35 \% \text { of } \\
\text { costs }\end{array}$ \\
\hline PLS & Intermediate & 28 & $\begin{array}{l}30 \text { years: } \\
50 \text { for land } \\
\text { purchase }\end{array}$ & $€ 5100$ & $€ 4700$ & $€ 3600$ & $\begin{array}{l}€ 7.11 \text { to } \\
€ 9.36 / \mathrm{m}^{2}\end{array}$ & $\begin{array}{l}\text { Varies; } \\
\text { TLA }+1.10 \%\end{array}$ & $\begin{array}{l}\text { VAT } 5.5 \% \text {; no } \\
\text { property tax for } \\
25 \text { years }\end{array}$ & $\begin{array}{l}\text { Associated subsidy of up to } 10 \% \text {. } \\
\text { Affordability maintained during } \\
\text { contractual period of } 15-30 \text { years. } \\
\text { After this rents on units owned by } \\
\text { HLMs remain regulated but private } \\
\text { landlords can rent at market rates. }\end{array}$ \\
\hline PLI & $\begin{array}{l}\text { Upper } \\
\text { intermediate }\end{array}$ & $\begin{array}{l}\text { Not officially } \\
\text { considered } \\
\text { social } \\
\text { housing }\end{array}$ & $\begin{array}{l}30 \text { years: } \\
50 \text { for land } \\
\text { purchase }\end{array}$ & $€ 7200^{* *}$ & $€ 5300^{* *}$ & $€ 4900$ & $\begin{array}{l}€ 7.25 \text { to } \\
€ 17.37 / \mathrm{m}^{2}\end{array}$ & $\mathrm{TLA}+1.39 \%$ & $\begin{array}{l}\text { Landlord can } \\
\text { exclude } \\
\text { proportion of } \\
\text { income from } \\
\text { tax } \\
\text { (percentage } \\
\text { depends on } \\
\text { year of } \\
\text { acquisition) }\end{array}$ & $\begin{array}{l}\text { Available in cities and other pressure } \\
\text { areas. Affordable during contractual } \\
\text { period of } 9-30 \text { years. After this rents } \\
\text { on units owned by HLMs remains } \\
\text { regulated but private landlords can } \\
\text { rent at market rates }\end{array}$ \\
\hline
\end{tabular}

Note: * TLA = taux du livret A. TLA averages 3\%; ** Under 'Scellier scheme'.

Source: Oxley (2009); Caisse des Dépôts; Ministere de l'Ecologie, de l'Energie, du Developpement durable et de la Mer; Levy-Vroelant and Tutin (2007); Agence nationale de l'Habitat (2010). 
Maximum rents apply to PLUS housing; these also vary by region. An income ceiling applies to households wishing to access PLUS housing, and this income limit serves as a basis for calculating the income limits for other types of subsidised loans. Before 1977, standard social housing amounted to $81 \%$ of all social stock, but this has fallen to under $70 \%$ in recent years as state policies have favoured housing for households with higher incomes.

The PLA-I, the second type of social-housing loan, finances housing for very deprived households. It has much lower interest rates and permitted rents are lower, as are maximum household incomes. Intermediate housing is financed by a third type of loan, the PLS. About a quarter of such loans are taken out by private landlords (individual or institutional), rather than by HLMs; these loans can be attractive for the private sector because after a contractual period of 15 to 30 years, the housing built with the loan can be sold or rented at market price. PLI loans are similar to PLS loans but target an even higher income group, and the limits on rents and incomes are higher than for the PLS. The dwellings financed by PLI loans are not officially classed as social housing.

\section{Demographics}

The French system has traditionally been universalist one - that is, aiming to provide housing to a broad spectrum of social and income groups - rather than residual or targeted. However, universalist systems have come under increasing pressure from the European Union, which holds that subsidising housing for middle-income groups is not a legitimate use of state aids under European legislation.

Household income ceilings apply for social housing; these ceilings depend on the type of loan that financed the housing and are fairly high. For a standard social housing unit in 2006, the income limit was nearly $€ 40000$ for a household with two children, and in that year $71 \%$ of French households would have been eligible; by 2008 the proportion had risen to over $75 \%$. In the same year, 35\% of households would have been eligible for 'very' social housing, and $80 \%$ and $89 \%$ for the two types of intermediate housing. These were historically high levels for France, and were high in comparison to income ceilings in other countries. In March 2009 the 'Boutin' law was passed, which reduced income ceilings for standard social housing by $10.3 \%$; the percentage of the population eligible fell from over $75 \%$ to about $65 \%$. This is still high by European standards. Intermediate housing in particular has very high income ceilings by international standards, and arguably houses families who have no need for state subsidy to access adequate housing.

Immigrant households made up $9.5 \%$ of the total population in 2002, but they occupied $22 \%$ of the social rented units. Some $29 \%$ of immigrant households lived in the social rented sector, compared to $14 \%$ of non-immigrants. But for households from Turkey, the Maghreb and black Africa, this percentage was far higher: 44\%, 48\% and 38\% respectively (Levy-Vroelant. and Tutin, 2007). The average immigrant household size was larger than that of non-immigrants: in the social sector, the average number of persons per household was 3.5 for immigrants and 2.4 for non-immigrants.

Despite its universalist origins, and the recent emphasis on building housing for higher-income groups, the social sector now increasingly houses poorer families. Social tenants have lower incomes than tenants as a whole, and much lower than owner-occupiers. The concentration of poor households in the social sector has been growing over the last decades; one recent study showed that a quarter of new tenants had household incomes of below $20 \%$ of the relevant ceiling.

\section{Access}

Several groups have the right to nominate tenants for social housing, in exchange for having contributed to its financing. Thus $30 \%$ of the housing is reserved for tenants nominated by the prefect (as 
representative of the State); within this 30\%, 25\% is for the most needy and 5\% for State employees. As local representative of the central state, the prefect is supposed to administer these, but in most places they either do not use this power or delegate it to mayors. Another $20 \%$ of the dwellings are reserved for those nominated by the commune in return for contributions (in cash, land or other) to social housing construction. Of the remaining half, most is reserved for the comités interprofessionels du logement, which collect a compulsory hypothecated tax from the incomes of employees. This tax is used to build new social housing or upgrade existing housing. The comités can allocate these spaces to contributing workers, who are sometimes poor but not generally among the most disadvantaged (Ball, 2008).

The final allocation decision is taken by the social landlord's allocation commission (Ball, 2008). A recent study found that allocation commissions generally rejected only 1 to $5 \%$ of applicants - often those with the greatest needs. This was in part because the funding system provided landlords with up-front loans for construction but no money to meet tenants' social needs later.

While standard income limits apply across France for the various types of social housing, providers can draw up their own additional eligibility criteria for prospective tenants. These often differ from one social landlord to another. Social landlords can take into account the concerns of existing tenants and whether the applicant can pay the rent.

Tenancies are for an unlimited period, and until recently there was no procedure for evicting tenants whose incomes later increased. While HLMs were permitted to charge a rent supplement to such households, in practice it was rarely done. The Boutin law of March 2009 changed this: leases to households with incomes equal to or greater than twice the ceiling are changed to three-year non-renewable contracts. According to a 2006 survey this would only affect about 35000 household nationally (Driant, 2011). This law also requires social landlords to try to re-house tenants who are "clearly under-occupying' their unit. Tenants in high-demand areas who refuse three offers lose their tenancy rights after six months. The elderly and disabled are exempt from this provision.

\section{The 'opposable right' to housing}

Since 1990, disadvantaged people have had a right to housing in France. Article I of the loi Besson, no. 90-449 du 29 mai 1990, states:

"Every person or family experiencing particular difficulties, particularly by reason of insufficiency of financial resources or their condition of existence, has the right to an aid from the government, in the conditions fixed by the present law to obtain access to a decent and independent home or to maintain themselves there".

This was reinforced in 2007 by the loi instituant le droit au logement opposable, allowing some disadvantaged groups to take legal action against the state in administrative tribunals to seek social housing (Ball, 2008). This 'opposable right' to housing (known by the French acronym DALO) means that someone can be sued to enforce it; it thus amounts to a legally enforceable right to housing. However, use of the procedures set out in the law gives access to at most $30 \%$ of social housing allocations, and then only after an arduous process which still allows social landlords to refuse to house a successful litigant. Although the law gives a right to housing, there is little extra money associated with it, and the right does not allow access to those parts of the housing stock earmarked for mayors, workers and existing tenants.

In practice, this 'right' to housing comes up against the fact that there are not enough vacant social housing units, particularly in areas of high housing pressure like the Paris region. The situation will be exacerbated after 2012, when the law will accord housing priority to those who have experienced 'an 
abnormally long delay' in securing housing; having spent a long time on the waiting list will apparently suffice.

The law as it stands imposes no duties on local actors and does not change allocation procedures; it is only a supplementary procedure for a small amount of stock. The coming expansion of the group that is eligible to claim this right, and the reluctance of some municipalities to add to their social housing stock, may exacerbate pressures on this system.

\section{Rents}

As in much of the rest of Europe, social housing rents are set on the basis of formulae that reflect the initial cost of construction and the means of funding; they are not related to market rents. This means that rents can and do vary significantly within local areas. They tend to be lower for buildings financed under previous schemes. There are four geographical classifications, with Paris having the highest rents. The variety of schemes and corresponding rent regulations makes for an opaque and inconsistent system: 'This regime is applied to a very wide range of situations in terms of the financing of the original construction of the dwellings or the renovations they have undergone. It results in a great diversity of rent levels, which are not related to the various income ceilings that apply and even less to the quality of the dwellings or their locational advantages. The complexity of the range of social rents may have some financial logic, but lacks economic and social coherence, and helps make the sector opaque to the general public' (Driant, 2011, author's translation).

In general, social rents are much lower than in the private sector. The difference is $30 \%$ to $40 \%$ on average, but can be much higher in bigger towns - notably in Paris, where the ratio of social to private rents is $1: 2$ or 1:3. The discrepancy between private and social rents increased rapidly with the growth of house prices since 1997, making it impossible for most tenants to leave the social sector for the private sector.

Most tenants benefit from housing allowances. On average, APL (Aide Personnalisée au Logement) covers $60 \%$ of the rent for the poorest $10 \%$ of households.

\section{Social home ownership}

In order to address the lack of mobility between the social rented and private sectors there have been attempts to develop social home ownership. For example, the PTZ+ (prêt a taux zero plus) programme offers $0 \%$ loans to first-time buyers including social tenants who want to buy. This serves the double goal of enabling families to become home owners and freeing up spaces in the social stock. There is concern, however, that such loans can have the effect of increasing prices in the owner-occupied sector, given that this is purely a demand-side subsidy not associated with any increase in supply.

\section{International experience}

Each country's individual housing system reflects its own history, legal framework, economy and climate, so solutions cannot simply be read across from one country to another. Nevertheless, as in all areas of social policy, international comparisons can provide useful benchmarks and point to areas of best practice. 


\section{General background}

Size of stock

Table 2 gives figures for social rented housing as a percentage of all housing in various European countries, the United States and Australia in three periods: the early 1990s, the early 2000s and latest. The rather patchy nature of the table reflects the statistics available, which are not always collected in a consistent or timely manner across countries. The most recent comparable figures are from 2007, but tenure shifts happen slowly and the current figures are probably not much different. In Greece there is no social housing at all, and in Spain it makes up only $1 \%$ of the stock. At the other end of the scale, in the Netherlands $35 \%$ of housing was social rented in 2007; this represented a fall from the early 1990 s, when it was over $40 \%$. In general the countries of northern and western Europe have higher percentages of social housing, while countries in southern Europe have lower percentages. Many eastern European countries (Hungary, Slovenia) have rather small social housing sectors, having privatised much or all of their state-owned housing after 1989, although in Poland and the Czech Republic the sector is about the size of France's.

Table 2. Social rented housing as per cent of all housing, early 1990s, early 2000 s and 2007

\begin{tabular}{|c|c|c|c|c|c|}
\hline & $\begin{array}{c}\text { Early } \\
1990 \text { s }\end{array}$ & Year & $\begin{array}{l}\text { Early } \\
2000 \text { s }\end{array}$ & Year & 2007 \\
\hline \multicolumn{6}{|l|}{ EU countries } \\
\hline Austria & & & & & 21 \\
\hline Belgium & & & & & 7 \\
\hline Czech Republic & & & 15 & 2001 & \\
\hline Denmark & & & & & 20 \\
\hline England & 22 & 1993 & 20 & 2001 & 18 \\
\hline Finland & 10.7 & 1992 & & & 18 \\
\hline France & 15 & 1990 & 17 & 2002 & 19 \\
\hline Germany & $15^{\star}$ & 1987 & 7 & 2003 & 6 \\
\hline Greece & & & & & 0 \\
\hline Hungary & & & 4 & 2001 & \\
\hline Ireland & 13.9 & 1987 & & & 8.5 \\
\hline Italy & & & & & 5 \\
\hline Luxembourg & & & & & 2 \\
\hline Netherlands & 40.2 & $1993 / 4$ & & & 35 \\
\hline Poland & & & 16 & 2002 & \\
\hline Portugal & & & & & 3 \\
\hline Slovenia & & & & & 4 \\
\hline Spain & 1.1 & 1990 & 1 & 2001 & 1 \\
\hline Sweden & 22 & 1991 & & & 21 \\
\hline \multicolumn{6}{|l|}{ Non-EU countries } \\
\hline Australia & 6 & 1994 & 5 & 2001 & \\
\hline United States & 2 & 1990 & 3 & 1999 & $2.3^{* *}$ \\
\hline
\end{tabular}

Note: *former West Germany only; **2008 figure.

Source: All Danish figures calculated from Statbank Danmark, Table BOL 30; all England figures from Department of Communities and Local Government Live Table 104 (Dwelling stock by tenure: England). Other early 1990s figures from Freeman et al. (1996). Other early 2000s figures Fitzpatrick and Stephens (2007). Other $2007 \mathrm{EU}$ figures from Czische and Pittini (2007). US figure calculated from American Housing Survey and A Picture of Subsidized Households, US Department of Housing and Urban Development. 
The table also shows changes over time for some countries. In Ireland, the Netherlands and the United Kingdom the relative size of the sector has fallen over the last 20 years, but in Finland and France it has grown. Germany represents something of a special case as the earliest figure is for West Germany only while the later figures are for the reunited country; nevertheless the stock in western Germany alone contracted between 1990 and 2000 (Stephens et al., 2002). In former east Germany many cities have sold some or all of the former municipal housing stock to private investors. In most cases it continues to function as social housing, but only for a limited period.

\section{Providers}

The nature of social-housing providers differs across countries. In some countries (Hungary, Sweden) all social housing is municipally owned, while in the Netherlands nearly all is owned by housing associations, although these have traditionally been guaranteed by municipalities. England ${ }^{2}$ is in the middle, with a nearly 50/50 split. The general trend is towards declining municipal involvement and increasing diversity in the range of actors involved in social provision - notably through public-private partnership and efforts to involve the private sector as providers.

\section{New construction}

In most industrialised countries, the requirement for all types of housing is increasing. The main exceptions are the shrinking cities of former East Germany, where there are large amounts of surplus poor-quality social housing, and some low-demand areas of Europe (especially Sweden and northern England). There is therefore a revival of pressure to expand supply - both overall and social. Meeting these demands often involves using public-sector land.

Table 3 gives new social housing as a percentage of all residential completions. The most recent year for which comparable data were available was 2005. In most countries this percentage is similar to the percentage of social housing in the overall stock. Exceptions include Austria, where social housing was a bigger percentage of new construction than of the existing stock, and the Netherlands, where it was much less. These figures should, however, be viewed as indicative only since they are not from the same year as the stock data, and new construction can vary much more than overall tenure. Recent figures for the United Kingdom at least show a very different pattern, with social housing making up an unusually large percentage of residential construction - in the first quarter of 2009 , more than one-third of housing starts were by housing associations. This reflects the dramatic effect of the financial crisis on private-sector residential construction, and the effects of government financial stimulus programmes which have channelled funds into social housing construction.

\footnotetext{
${ }^{2}$ References in this document are generally to England rather than to the United Kingdom. Housing policy in Scotland, Northern Ireland and particularly Wales is usually similar to English policy, but not always. Most comparative housing-policy literature refers to England or Scotland rather than the UK.
} 
ECO/WKP(2011)31

Table 3. Social housing as per cent of all housing completions, EU countries

\begin{tabular}{lcc}
\hline & Per cent & Year \\
\cline { 2 - 3 } Austria & 30 & 2005 \\
Belgium & 6 & 2005 \\
Czech Republic & 20 & 2005 \\
Denmark & 13 & 2005 \\
England & 11 & 2005 \\
Finland & 12 & 2005 \\
France & 9 & 2005 \\
Germany & 9 & 2005 \\
Hungary & 4.5 & 2005 \\
Ireland & 6.3 & 2005 \\
Luxembourg & 0.6 & 2003 \\
Netherlands & 12.8 & 2005 \\
Poland & 8.3 & 2005 \\
Spain & 10.3 & 2005 \\
Sweden & 16 & 2005
\end{tabular}

Note: All 2005 except Luxembourg (2003), UK (2008/09).

Source: Czische and Pittini (2007) except for England, from Department of Communities and Local Government Live Table 209 (Housebuilding: permanent dwellings completed by tenure and country).

Funding and subsidy

\section{Approaches to funding}

Social housing everywhere involves large scale subsidy often to both capital and revenue. However, the general trends across Europe have been to move away from revenue and interest-rate subsidies, particularly because these can be open-ended, in favour of capital grants that can both be cash-limited and targeted more effectively at particular groups and localities.

Most municipalities across Europe have found it difficult to maintain their contributions to additional housing as their responsibilities increase and property tax receipts have not kept pace with costs. In some places, notably England, the State has placed additional constraints on local authorities, limiting their involvement in social housing. The more general trend is for lower levels of involvement by municipalities, in part because of the growth of independent social landlords.

A further trend has been away from supply-side subsidies towards income support for poorer tenants. This may make it possible to use the existing stock, especially that in the private sector, more effectively, but generally provides few incentives for additional investment. As a result output of new housing has declined significantly in many countries. The most extreme example was Sweden in the 1990s, when the removal of interest-rate subsidies stopped building across almost all sectors (Turner and Whitehead, 2002).

In general, the reduction in subsidy has led to a fall in investment in social housing. The exception here is undoubtedly France where the continued supply of subsidised debt finance has enable development to be maintained. In the Netherlands social landlords also have considerable capacity to increase investment without recourse to subsidy but they have little incentive to do so, especially as the government has increased their responsibilities for regeneration and local area management. Finally, the global financial crisis has seen a move back to direct subsidy to social housing - often as a way of helping developers as much as providing social housing. 
The traditional role that debt finance has played in the social sector has been to enable new investment to be undertaken, usually with the help of subsidy. Over the last twenty years, as financial markets have been deregulated and opportunities for borrowing have increased, social housing providers have moved to privatise the existing stock and use the equity capital as collateral for further borrowing, either for housing purposes or to reduce public borrowing elsewhere.

In many European countries the traditional forms of debt finance were either through the public sector, which provided loans at 'risk-free' interest rates, or through interest-rate subsidies to independent social landlords enabling investment to be undertaken at lower cost. In many cases additional guarantees from either local or central government were provided, to further reduce interest rate costs. This was particularly the case in Scandinavian countries and in the Netherlands. But in almost all European countries social housing was very much dependent on special circuits of finance where costs were significantly below market levels.

Over the last decades this special treatment has been much reduced. Interest-rate subsidies have been removed and providers have more and more been expected to borrow on the private market (although often benefiting from explicit or implicit government guarantees as well as the security of rental income achieved with the help of income related support).

The markets for large scale borrowing by social landlords undertaking new or improvement investment has been most developed in the Netherlands and in England. In both countries risk premia have been reduced to minimal levels and there have been many providers of debt finance. Whether this situation will be maintained in the face of the current financial crisis is as yet unclear. But asset values are generally high and rental revenues relatively secure so perhaps the longer term future is reasonably secure.

More generally, the capacity to raise debt finance depends heavily on the certainty of the rental stream, on the one hand, and the capacity to realise capital values on the other. Where these rights are restricted it may be difficult or impossible to raise debt on the private market.

\section{New construction and renovation}

Funding for new construction and renovation (capital funding) can be distinguished from revenue finance, which covers the ongoing costs of social housing. In general, social housing providers in Europe raise the bulk of their capital funding by borrowing from either public- or private-sector lenders. They use the value of their housing stock as collateral and the secure rental stream from social tenants (normally backed up by some form of housing benefit) as the revenue stream to make repayments. These loans are sometimes guaranteed by the government or a public body, as in Denmark or the Netherlands. More often, however, the fact that social-housing providers and lenders are themselves both supervised by government regulators is considered to provide adequate levels of security. Loan repayments are made from the housing provider's rental income, which is often directly related to the cost of provision (see below). In a few countries - the Netherlands is the main example - social housing providers have significant reserves, and can finance new development from their own resources.

Although most of the cost of new social-housing construction is usually covered by loans, tax concessions or government subsidies are normally required in order to bring the cost down to a level affordable by target groups. Table 4 summarises the ways of structuring government support for social-housing finance found in developed countries. 
ECO/WKP(2011)31

Table 4. Government policies to support supply of new social housing

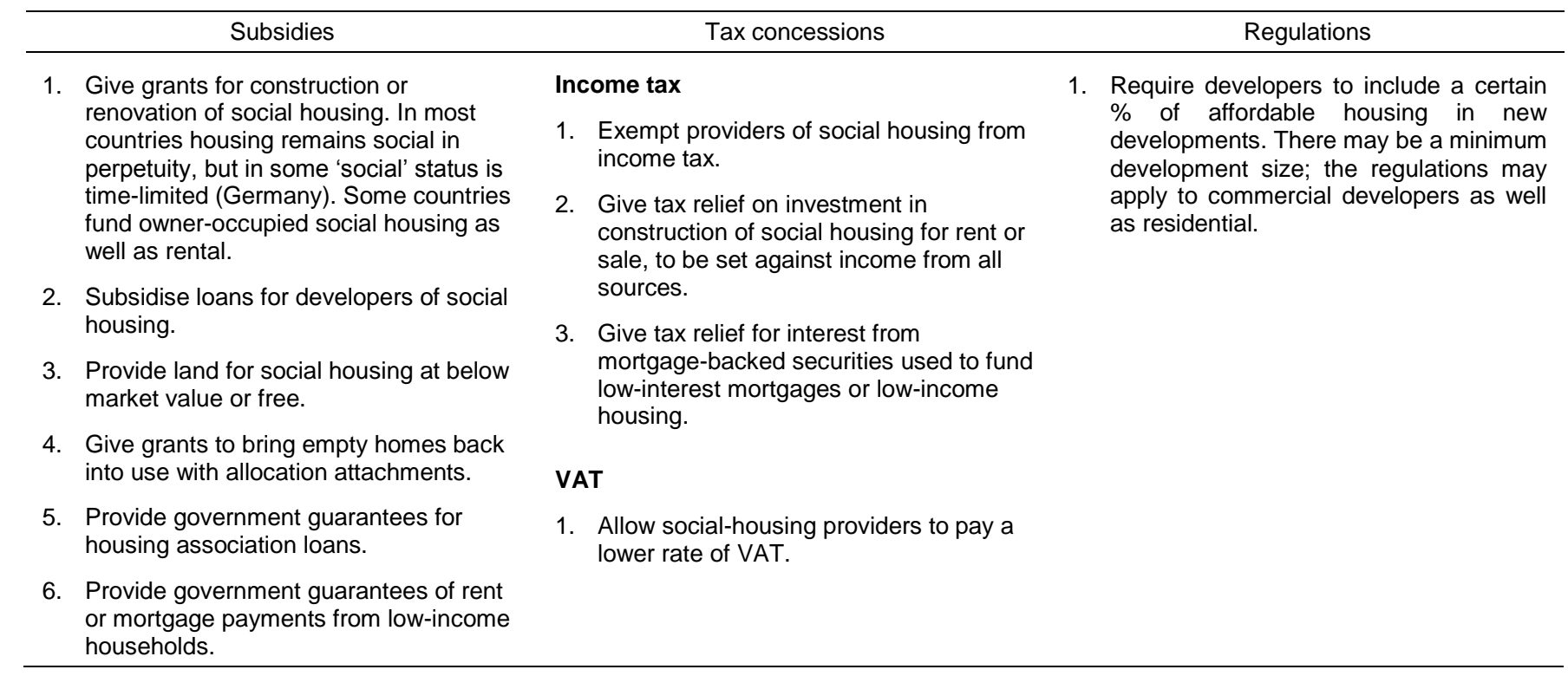

Source: Derived from Holmans et al. (2002); Whitehead and Scanlon (2007).

In most countries new social housing is expected to remain social in perpetuity, but in several its 'social' nature expires after a period of years or decades and the dwelling can be rented or sold at the market price. For some time the bulk of new social housing in Germany has been built by private or non-profit developers in receipt of government grant; the housing thus provided has to be let as social for a limited period only. The Czech government has recently introduced a similar system. In Spain, subsidies are given for social owner-occupied (rather than rental) housing. Traditionally, social housing in Spain is mainly provided through subsidized owner-occupied dwellings that are sold at below-market prices to households with low and middle incomes. For a limited number of years, during the so-called qualification period, these dwellings keep a protected status, which means that they may not be sold against market prices. Only when the qualification period has expired does the housing concerned become part of the 'normal' housing stock' (Hoekstra et al., 2010, p. 126). Some of Spain's autonomous communities have recently acted to extend this qualification period or even eliminate it altogether in order to ensure that the homes remain permanently in the social stock.

\section{Case study: The Low-Income Housing Tax Credit in the United States}

One example of a subsidy to private developers to provide social housing for a limited period is the US Low-Income Housing Tax Credit (LIHTC), the main example of a tax credit for construction of affordable housing. The LIHTC is now the principal US federal subsidy for low-income housing. This programme was introduced in 1986 and has been operating, with some modifications, since then (Desai et al., 2009).

The essentials of the programme are as follows:

"The intent of the program is to provide enough incentives to ensure that there will be an adequate supply of low-income housing by granting tax credits to the owners of selected rental housing developed for occupancy by low- or moderate-income households. Although the subsidy is provided entirely through the federal tax code, it is administered through state government agencies, generally 
the state housing finance agency. States may allocate these tax credits annually up to a total equalling $\$ 1.25$ per capita" (McClure, 2000, p. 92). (Note: This was raised in 2003 to $\$ 1.75$ per capita and then indexed for inflation.)

The tax credits are always tradeable instruments, and investors pay between $60 \%$ and $95 \%$ of their face value (depending on the type of project and the risk involved); the price at which they traded increased over the life of the programme before falling after the financial crisis. If incentives are not tradeable, it limits involvement in tax-incentivised projects to large companies - those that have enough resources to fund projects on their own, and that are certain to have enough tax liabilities, for a long enough period, to make use of the tax incentives. This rules out charities and other exempt bodies such as pension funds, which do not pay corporation tax. If the incentives are tradeable, however, even small firms or charities can participate in the programme by selling the tax incentives to investors for cash. The US rule of thumb is that a liquid (tradeable) instrument is worth about $20 \%$ more than an illiquid (non-tradeable) one.

The subsidy is not given automatically to all housing developments for low-income renters, but is discretionary. Developers of individual projects - either new construction or rehabilitation of existing properties--apply for subsidy in the state where the project is located, and each state selects using a competitive process. When the development is finished and the units are occupied, the property owner starts to receive tax credits. These credits continue to flow for ten years, provided that the units are occupied by eligible households for at least 15 years.

Tax credits are given only for those units occupied by eligible households. For the development as a whole, one of two conditions must be met:

- At least $20 \%$ of the units are occupied by households whose income is less than $50 \%$ of the metropolitan area's median family income, or

- At least $40 \%$ of the units are occupied by households whose income is less than $60 \%$ of the metropolitan area's median family income (McClure, 2000, pp. 92-94).

These income ceilings $-50 \%$ or even $60 \%$ of median family income - are low; in the UK context they would be about the median for social rented tenants.

The programme has evolved considerably since its creation. For example, the original affordability period was 15 years; later it was amended to 15 plus 15 (the latter based on a formula price), and most recently to 30 years, with many states requiring longer affordability periods, some up to perpetuity. One drawback of the system, however, is that the value of the credits fluctuates with market conditions, and the market for them has been seriously affected by the global financial crisis - arguably just at the time that new affordable housing investment is most needed (Desai et al., 2009).

\subsubsection{The role of equity finance}

Many European social housing providers hold unencumbered capital assets on which no return is required. They also own land and other assets. Their assets are often used in regeneration projects, especially those that involve increasing the density of provision. Finally many social sector providers have significant reserves built up from part subsidies and from rental income. These assets enable rents to be held down. They also present opportunities to enable additional investment, particularly by providing internal subsidies in the early years which can be reimbursed as rents rise into the longer term and surpluses are made. This is particularly the case in the Netherlands, the United Kingdom and Scandinavian countries. 
The most usual approach to increasing the use of equity finance however has been through the sale of homes to sitting tenants, often at a discount. The objective is usually that of enabling tenants to achieve owner-occupation while, at the same time, funds can be recycled to extend social provision (or for other goals). The Right to Buy in England has been the largest such programme, involving the transfer of over 1.6 million units to tenants. These transfers involve a proportion of equity and debt finance put in by the tenant as well as subsidy from government. Other countries have similar programmes, although the extent of subsidy is usually less than was originally involved in the Right to Buy. Ireland has had a long standing programme which has enabled large scale sales. The Netherlands has had a significant programme for a decade or more. Sweden is looking at extending their programmes. More generally, supporting owner-occupation is seen as a cost effective way for government to subsidise housing for those able to contribute more to their housing costs than the majority of those in social housing. Linked to this has been a growth in interest in programmes to support low-cost home ownership where purchasers buy a part of their homes; there is a wide range of specific schemes that fit the legal and institutional arrangements of individual countries. The cooperative home ownership schemes prevalent in Scandinavia are perhaps the best established. Community Land Trusts are also important in a number of countries, notably Germany. A wide range of new approaches are being developed in most Northern European countries, most involving the introduction of individual equity and debt finance.

The latest, and arguably the most drastic, initiatives involve bringing private equity into the ownership of the existing stock of social rented housing. So far Germany provides the only working example of large scale private equity involvement in the existing stock. There have been two main approaches: the sale of the whole municipal stock in a small number of large cities, notably Dresden and Kiel in the East; and far more limited sales of parts of the stock across a range of smaller municipalities, mainly in what was West Germany.

The principles involved are straightforward. A license is specified, clarifying the conditions under which tenancies are to be provided, including how rents may be set, when evictions may take place etc. It also clarifies the rights of the new owner to sell properties, demolish and redevelop them, and their responsibilities with respect to management, maintenance and improvement. These conditions help to determine the price at which the properties are sold - so there are difficult incentives/ disincentives when determining the license. These disposals have been seen simply as a way for the municipalities to get out of housing (although their responsibility to house the vulnerable remains). More positively they can be a way of increasing the efficiency of social housing provision and the better use of public resources.

In England and the Netherlands, social housing has been transferred to the independent sector, in England through large-scale voluntary transfers from municipal owners and in the Netherlands simply by ring-fencing the sector. In neither country has true private equity finance been involved. However, in both countries it is possible to create public/private partnerships for development and regeneration which could lead to both developer and institutional equity finance.

\section{Private-sector social supply}

Several countries, including Germany, the United States and Australia, have programmes to encourage private-sector providers to build and operate social housing. In exchange for agreeing to house low-income households providers receive various incentives (long-term rental contracts, rent guarantees, financial support and fiscal advantages). The social character of the resulting housing is often time-limited. In Germany and the United States such programmes have over time boosted the size of the private rented sector considerably, as social dwellings have moved to the private sector. Australia's programme is new and small-scale (Oxley, 2010). 


\section{Approaches to rent determination}

Central governments generally set out the basic principles by which rents in the social sector should be determined. However they have varying levels of involvement with respect to the individual property and area. At one extreme, notably in England and the Netherlands, property rents are related to the valuation of the individual property as well as to area based incomes. At the other, as in Denmark, they may be determined by the managers of a specific estate in relation to the costs to be covered for that estate.

Governments are generally looking to ensure a financial framework which puts pressure on owners and managers of the social rented stock both to operate efficiently and to provide effectively for target groups. The most usual approach is to require providers to break even or to achieve a target rate of return on assets (whether valued at historic or current cost). These financial constraints may operate at the level of the social sector as a whole (the Netherlands); the provider (England); or the estate (Denmark). Each approach generates its own tensions, notably with respect to the capacity to cross-subsidise between areas and cohorts of investment.

It is important to recognise the distinction between rent structures and rent levels. The majority of government regulation across Europe concentrates on levels: determination of relative rents is left to the owners to be based on values, needs or other criteria.

Rent levels depend upon the interaction between the government regulatory framework, the source of funds, the extent of subsidy and the timing of part investment. Over the last few years, where investment has declined, the pressure to increase rents has also usually lessened. In some countries, notably Sweden, the Netherlands and France, rents are set well below market levels but access to social housing is available to a large proportion of the population, which has become a matter of concern for EU competition policy. In other countries notably Ireland and the United Kingdom where rents are often far below market levels access is much more restricted, targeting poorer households.

There are four broad methods of setting social rents (Oxley, 2009):

- Setting rents at a level that will cover the costs of provision ('cost rents');

- Using a formula, so the rent for a dwelling is a function of its size, quality and location ('utility value');

- Charging a percentage of tenant incomes;

- $\quad$ Basing them on market rents, with a discount to make the properties affordable.

The major benefit of cost based rents is that they are most directly related to the subsidy provided because the cost of production and running the stock less subsidy equals rents required. The most obvious problems relate to inefficiency as there is nothing to ensure that costs are at their minimum. There have been many instances, notably in Denmark, Germany and Austria, where costs have clearly been inflated. More complex issues arise when costs become disconnected with values so the difference between social rents and the value to the consumer may become very large.

The benefit of value-based systems is that they relate to what consumers regard as important. However there are then no direct links either to the subsidy that government has provided or to the actual costs of maintaining the social stock. Most importantly government generally requires that in exchange for subsidy rents should be held below market values and bear a clear relationship to affordability among the target groups of households. There is thus inherently excess demand and few of the allocation benefits that flow from relating rents to value can readily be realised. Both England and the Netherlands have developed systems that set rent structures in relation to capital values but modify the rents actually charged in relation to income. 
Rents related to income, as seen in Ireland the United States and Australia (as well as Belgium, Luxembourg, Portugal and parts of Germany), fail to reflect market forces. In addition, they generate inadequate revenue streams and make it more difficult to employ private finance in the sector especially if the households accommodated are particularly concentrated among lower income groups, and if their incomes are rising more slowly than the costs of managing and maintaining the stock. Countries where rents are related to income tend to have small social sectors.

Finally there are examples where rents are related to those in the private sector rather than directly to capital values. This approach is particularly prevalent in countries where private rents are also controlled. The most important example of this approach has been Sweden and to a lesser extent the Netherlands and Germany. In these countries there is usually an understanding among those who set social and private rents as to the expected relativities, which are usually a matter of negotiation rather than related to specific formulae. For instance, in Sweden, the role of the unions has continued to be at the heart of the negotiation process.

Table 5 provides some details on how rents are set both in the social and the private sectors across Europe. It reflects all four types of approach to rent setting as well as different ways of addressing the issues of historic versus current cost. In some countries, rents together with available subsidies provide social-sector revenues that are more than adequate to enable owners to build reserves and to make contributions to additional provision. This is particularly true of the Netherlands where the housing associations are expected to be self-sustaining. In other countries the revenues are inadequate effectively to maintain the stock, let alone support new investment, notably in Eastern Europe and in Ireland but also in parts of Germany.

Table 5. Social and private rent determination

\begin{tabular}{|c|c|c|}
\hline & Social & Private \\
\hline Austria & Cost-based. & $\begin{array}{l}\text { Also cost-based; private }<10 \% \text { higher (in } \\
\text { post- } 1953 \text { buildings there is de facto no } \\
\text { regulation). }\end{array}$ \\
\hline Denmark & Cost-based. $3.4 \%$ of building cost + bank charges. & $\begin{array}{l}\text { Private rents also regulated for most dwellings } \\
\text { built before 1991; higher than social rents. }\end{array}$ \\
\hline England & $\begin{array}{l}\text { Rent restructuring regime based on local earnings } \\
\text { and the dwelling price; increases RPI plus } 0.5 / 1 \% \text {. } \\
\text { Housing associations and local authorities must } \\
\text { cover outgoings. }\end{array}$ & Market determined for properties let since 1988. \\
\hline France & $\begin{array}{l}\text { Central government decrees maximum rents, } \\
\text { which vary by region. Cost-based related to estate } \\
\text { or owner. }\end{array}$ & $\begin{array}{l}\text { Rent on new leases free, but rises regulated. } \\
30-40 \% \text { higher than social rents. }\end{array}$ \\
\hline Germany & In some states rents vary with household income. & Rent on new leases free, but rises regulated. \\
\hline Hungary & Set by local authorities. & Market. \\
\hline Ireland & Tenants pay \% of income in rent. & Rent control abolished 1981, now market. \\
\hline Netherlands & $\begin{array}{l}\text { Rent based on utility value of dwelling and target } \\
\text { household income level. }\end{array}$ & Also controlled; higher than social rents. \\
\hline Sweden & $\begin{array}{l}\text { Set by annual negotiation between landlords and } \\
\text { tenants. }\end{array}$ & $\begin{array}{l}\text { Private rents limited by social rents; private slightly } \\
\text { higher. }\end{array}$ \\
\hline United States & $\begin{array}{l}\text { Tenants in HUD-assisted public housing pay } 30 \% \\
\text { of income; federal government pays remainder. }\end{array}$ & $\begin{array}{l}\text { Market determined. In New York City and some } \\
\text { other municipalities, rents are controlled on some } \\
\text { older units. }\end{array}$ \\
\hline
\end{tabular}

Source: Derived from Whitehead and Scanlon (2007). 
In many of the countries listed in Table 5 rents are cost-based - that is, they are set at a level that will cover the housing provider's financial outgoings (less supply subsidies where these are available), and are not related to market rents. In some countries the cost and rent calculations are done at the level of the individual estate, and relate to historic costs from when the estate was built or renovated. Thus older, often larger and better-located dwellings frequently have lower rents than newer, smaller, less well-located units. Estates that undertake large-scale renovation may be forced to increase rents beyond the capabilities of the tenants to pay. In these circumstances, renovation and even maintenance may not take place. This has been the case for example in Denmark, although there is a national fund that can subsidise renovation costs on needy estates.

Where rents are not calculated at the level of the estate they are normally calculated at the level of the organisation. In France rents may be estate- or owner-based, depending on the funding regime under which the dwellings were built. Rents cannot, however, be increased to cover maintenance and minor improvements, which creates an incentive to carry out larger-scale renovations, for which rents can be raised. In the Netherlands and England providers can pool rents across their whole stock, and rents can even be pooled across owners. In general it is preferable to employ a larger base for cost calculations, because this allows some cross-subsidisation from financially stronger estates to those which require investment.

The way that rents on individual dwellings are determined also differs between countries. In most countries they vary according to the attributes of the units. In the Netherlands, rents are directly related to the quality of the dwelling, as they are in England, but in both countries this is modified by an adjustment for tenant income.

A rather different issue is how rent increases are determined. These may be decided by governments (England, France and Hungary) or by negotiation between landlords and tenants (Sweden). In these circumstances, political pressures may intervene to affect rental income and therefore the landlords' capacity to maintain and improve stock.

In many European countries, private as well as social rents are by law related to costs; in others private rents are set by a mirror process linking private to social; in still others rents for new private lettings can be freely set but subsequent rent increases are constrained. Even in countries where similar rules apply to all rented housing, private rents are higher than social rents, but the scale of the difference depends on the specific regulatory framework. At the other extreme, where private rents are market-determined the differences between private and social rents may be very large indeed, especially in pressure areas (England and Ireland).

There is no agreement about the best way to set an equitable and efficient rent for social housing. Cost rents by definition cover historic costs, but have no direct relation to market forces and thus produce important distortions. Some housing experts in cost-rent countries (e.g. Denmark) thus advocate moving towards a more market-based system. Even rents based on 'utility value' (size and standard) do not necessarily reflect the relative desirability of individual dwellings and can lead to vacancies as well as excess demand.

There is thus very little consistency between countries in the ways that rents are set. Each depends upon a long history of financing and regulation which helps determine both feasibility and viability. History also often affects the link between rents and levels of provision as well as allocation rules. However the evidence across countries suggests that if rental income is not buoyant it will be extremely hard to maintain the social sector stock - leading to problems of dilapidation and social exclusion. So countries with low average rents, such as Hungary and Ireland, have affordable social housing but receipts 
do not cover costs, which tends to lead to major problems of management and maintenance. Finally, it should be noted that rent systems are generally bound up with housing benefit or rent allowance systems.

\subsection{Allocation across areas and the supply of land}

\subsubsection{The location of new social housing}

The location of new social housing can be a matter of political controversy. Local residents may resist what they see as an intrusion, while housing activists and overcrowded families may lobby for new construction - and often both pressures are seen in the same area.

In some countries the spatial distribution of funding (which determines the pattern of new construction) is determined at national level, while in others decisions are very local. In Denmark, for example, central government distributes grants for construction of new social housing to local authorities in accordance with a formula that takes into account demographic and social variables. The result is that even very small rural authorities are expected to build some social housing. In Finland, social housing was from the beginning scattered across urban areas in a conscious (and generally successful) attempt to avoid creating concentrations of poverty. In the United States, the Low-Income Housing Tax Credit is distributed to states on a per-capita basis, with no allowance for the particular needs or housing stock of individual states. The location of the resulting housing within each state is determined by the states themselves, who are free to set their own criteria. In England allocations are based on competitive tendering among Housing Associations in relation to identified requirements, while in the Netherlands there is no more direct subsidy and therefore the spatial distribution of new construction and investment in the existing stock depends on decisions by housing associations within a general regulatory framework.

The most important source of potential supply subsidy which does not require direct finance comes from land values - either through the use of public land for social housing at below opportunity cost or through contributions by landowners and developers to social and affordable housing. The very large post-war growth in social-sector supply across Northern Europe was often supported by the provision of free or cheap public-sector land. Over the last few years there has again been increasing emphasis on this source of funding, often because the transactions may not appear on public sector borrowing accounts because the ownership of land is not transferred.

In many countries local authorities or other public bodies supply land for the construction of social housing at below-market prices or even free of charge; this constitutes a subsidy in kind and was the traditional means of reducing financial subsidy requirements. This approach tends to result in provision in areas where local government has available land resources and there is a commitment to social housing rather than necessarily where the housing is most needed. In some countries, however, land can only legally be sold at market price - Denmark is one example; the United Kingdom is another as land must be sold to the highest and best use value. However the alternative of providing the land as an equity stake is acceptable (Scanlon, 2010).

A number of countries now require developers to provide land for social housing on new developments. This helps to reduce the price of land and provides implicit finance for the development. In Spain for instance all new developments must provide 30\% affordable home ownership as well as contribute to community infrastructure. In Ireland developments involving state land may have equivalent obligations.

\section{Case study: Section 106 in England}

The most highly developed policy that uses the planning system to provide land and finance for social housing can be found in England. It involves developer contributions negotiated at the time when planning 
permission is given and has given local authorities, and particularly London (where the Greater London Authority has regional powers as well), a powerful tool for increasing affordable housing output.

The approach to policy development was codified in the 1990 Town and Country Planning Act and the 1991 Planning and Compensation Act. As a result the land-use planning system could be used both to segment the market to ensure that land for affordable housing would be made available and owners and developers could be required to make a contribution to its costs. First, local development plans were to be put in place which would allow all interested parties to be involved in specifying the basic strategy for local development. Second, the provision of affordable housing was made a 'material consideration' for granting permission for residential sites. In particular, Section 106 (S106) of the 1990 Act made it possible for local planning authorities that could show the need for affordable housing at development plan stage, to require that a proportion of housing to be affordable on a site-by-site basis. Affordable housing was interpreted as either social rented housing owned by housing associations or low-cost home ownership, usually involving a subsidy and allocated by a housing association to specific groups, notably those either in social housing or on the waiting list. The vast majority of the contributions required were expected to be in the form of on-site provision of affordable housing, although there was the capacity for providing sites elsewhere or making a financial contribution where this was thought more appropriate. S106 also enabled the authority to ask for contributions towards transport, education and other social infrastructure.

Since 1990 central government has adopted additional policies. These aim to ensure mixed communities on new developments, emphasise on-site contributions, and shift the emphasis towards mixed-use developments so that housing (including affordable housing) is now often provided on what are basically commercial sites. This type of approach has also supported the development of mixed communities as well as intermediate tenures which help to provide affordable housing for key workers (Monk and Whitehead, 2010).

Section 106 aims to transfer planning gain benefit from the land owner to the local authority via the developer. The price the developer will pay for land is enhanced by the additional value created by planning permission less the anticipated cost of Section 106 agreements. Because the cost of Section 106 agreements are, in theory at least, expected to be borne by the landowner, they should not affect the ultimate price of housing or even influence the level of house building. However, it is important to note that the policy may in some cases cause land owners to delay sale of their land in anticipation of a policy change under different political leadership (Crook and Whitehead, 2002; Crook et al., 2002).

\section{Allocation of tenants to dwellings}

Social housing is normally allocated primarily on the basis of need. In general there are more applicants for social housing than units available, and prospective tenants must wait to be housed. In a few countries (e.g. the United States), applicants are housed in the order in which they joined the waiting list, but in most countries applicants are assessed on a combination of need and time on the waiting list.

In most countries there are income limits for households who wish to live in social housing (Table 6). The formal limits may, however, be so high that most of the population is eligible, as in Austria and France. Not all countries use formal income limits. In England, for example, the local authority could technically be required to house anyone in certain circumstances $-e . g$. if their house burned down or were compulsorily purchased. Allocation is not on the basis of income as such, but on the basis of what is known as 'priority need'- which is defined as having a household that includes children and/or a disabled or elderly person. In practice, though, the households who meet all the criteria for being housed by the local authority are almost always low-income. 
While most countries have maximum incomes for access to social housing, there are also some that apply minimum incomes, including Australia, Sweden and the Netherlands (Fitzpatrick and Stephens, 2007). This is designed to ensure that new tenants are able to pay the rent. In the Netherlands, for example, much of the social housing is well and expensively built, and very low-income families would not be able to afford the resulting cost rents.

In general, once a household gains access to social housing they are able to stay in the unit indefinitely and even, in some countries, pass the tenancy to their children. Income limits usually apply only at the point of entry; if a household's income subsequently rises they are not usually required to leave the sector. In several countries the rent remains unchanged, although the household would generally no longer be eligible for housing allowances. There is provision in some countries (e.g. Germany) for raising the rent, but in practice this rarely happens.

Table 6. Access to social housing: income limits

\begin{tabular}{|c|c|c|c|c|}
\hline & \multicolumn{2}{|c|}{ Income limits at entry } & \multirow{2}{*}{$\begin{array}{c}\text { Percentage of } \\
\text { population eligible } \\
\text { at entry }\end{array}$} & \multirow{2}{*}{$\begin{array}{l}\text { What happens } \\
\text { if income later } \\
\text { exceeds limit }\end{array}$} \\
\hline & Formal & De facto & & \\
\hline Austria & Yes & $\begin{array}{l}\text { Yes, but } \\
\text { rather high }\end{array}$ & $80-90$ & Rent unchanged \\
\hline Denmark & No & Yes & 100 & NA \\
\hline England & No & Yes & $100^{*}$ & NA \\
\hline France & Yes & Yes & $\begin{array}{l}\text { Varies by housing } \\
\text { type. About } 60 \% \\
\text { eligible for standard } \\
\text { social housing (has } \\
\text { ranged from } 55-65 \% \\
\text { over last } 20 \text { years }\end{array}$ & $\begin{array}{l}\text { If income is over } 2 X \\
\text { ceiling lease } \\
\text { changes to } 3 \text {-year } \\
\text { non-renewable } \\
\text { contract }\end{array}$ \\
\hline Germany & Yes & Yes & $\begin{array}{l}\text { Probably } 20 \% \text {, but } \\
\text { lower availability }\end{array}$ & $\begin{array}{l}\text { Municipality can raise } \\
\text { rent for those above } \\
\text { the limits, but rarely } \\
\text { does as it drives } \\
\text { people with social } \\
\text { capacity out of social } \\
\text { housing estates. }\end{array}$ \\
\hline Hungary & Yes & Yes & Very limited & \\
\hline Ireland & Yes & Yes & $\begin{array}{l}\text { No data but very } \\
\text { limited }\end{array}$ & Rent rises \\
\hline Netherlands & $\begin{array}{l}\text { Yes, for } \\
\text { affordable } \\
\text { housing stock** }\end{array}$ & Yes & $<40$ & Rent unchanged \\
\hline Sweden & No & Yes & 100 & NA \\
\hline
\end{tabular}

Note: *Access based on 'housing need', which is not strictly related to income. ${ }^{* *}$ Housing associations also provide more expensive dwellings, which are available to all.

Source: Derived from Whitehead and Scanlon (2007).

One exception to this is Norway, which has a very small social-housing sector ( $1.5 \%$ of dwellings) there leases on social housing are normally for only three years, as it is seen as a temporary recourse and not a permanent tenure. In Australia, two state governments introduced fixed-term tenancies for new social tenants in 2006. In Queensland, new tenants now have four-year leases (or twelve if they are elderly or disabled). On expiry of the lease, tenants who are no longer eligible for social housing are given help to 
move to the private rented sector. In New South Wales the duration of the lease depends on the income and age of the tenant and on household composition (Fitzpatrick and Stephens, 2008).

The Conservative-Labour coalition in the United Kingdom has recently questioned the advisability of indefinite social housing tenancies; in October 2010 the government announced its intention to allow social landlords to introduce fixed-term contracts and raise rents.

Table 7 summarises information about who sets the rules for access to social housing, and who determines the eligibility of individual households. In most countries the rules about who can live in social housing are set by central government, while local governments and/or providers determine eligibility of individual households (in Hungary, local governments are the providers through their Metropolitan Housing Companies.) In two of the countries with the most universalist systems, the Netherlands and Sweden, local government and providers set rules about eligibility, not central government.

Table 7. The allocation of social housing

\begin{tabular}{lccc}
\hline & Sets rules for eligibility & $\begin{array}{c}\text { Determines eligibility } \\
\text { of individual household }\end{array}$ & $\begin{array}{c}\text { Assigns household } \\
\text { to dwelling }\end{array}$ \\
\cline { 2 - 4 } Austria & $\mathrm{CG}$ & $\mathrm{LG} / \mathrm{P}$ & $\mathrm{LG} / \mathrm{P}$ \\
Denmark & $\mathrm{CG}$ & $\mathrm{LG} / \mathrm{P}$ & $\mathrm{LG} 25 \% / \mathrm{P} 75 \%$ \\
England & $\mathrm{LG}$ & $\mathrm{LG} / \mathrm{P}$ & $\mathrm{P}$ \\
France & $\mathrm{PG}$ & $\mathrm{P} / \mathrm{O}$ \\
Germany & $\mathrm{LG}$ & $\mathrm{P}$ \\
Hungary & $\mathrm{LG}$ (state) & $\mathrm{LG}=\mathrm{P}$ & $\mathrm{LG}=\mathrm{P}$ \\
Ireland & $\mathrm{LG}$ & $\mathrm{LG}$ & $\mathrm{P}$ \\
Netherlands & $\mathrm{CG}$ & $\mathrm{P}$ & $\mathrm{P}$ \\
Sweden & $\mathrm{LG} / \mathrm{P}$ & $\mathrm{P}$ & $\mathrm{P}$ \\
\hline
\end{tabular}

Note: CG: central government; LG: regional/local government; P: provider; O: other.

Source: Whitehead and Scanlon (2007).

Insider/outsider issues can arise when housing providers are responsible for assigning households to individual dwellings, with the result that 'insiders' get the best housing (or, where there is high demand, get housed at all). Partly to address this, the Netherlands and England have introduced choice-based lettings systems, where vacancies are advertised and households seeking accommodation 'bid' for the unit of their choice. In the Netherlands 'it seems that the limited influence housing association officials have on the allocation of housing has decreased discrimination' (Elsinga and van Bortel, 2011, p. 8).

\section{Demographics of social housing—where do the most vulnerable live?}

Social tenants have a particular demographic profile everywhere, even in Sweden and Denmark with their tradition of universal access. Social housing tends to accommodate the young and the old, as well as single parents and larger households (Table 8). Middle-income two-parent families prefer owner-occupation, and many countries have positive policies to promote it, supporting the departure of the middle class from social housing (conversely, in countries such as Spain, most new social provision is in the form of social owner-occupation.) This can be seen as a positive development - these households achieve their aspirations and the subsidies that go to provide social housing are better targeted. However, it also leads to income and tenure polarisation, particularly in places characterised by large mono-tenure housing areas. 
There is increasing concern in many countries about income and social segregation, especially on less desirable estates. This is true even those countries with large social sectors housing a broad spectrum of the population, such as the Netherlands and Denmark.

Each country defines, explicitly or implicitly, the main client group for social housing. In some it is the poorest members of society, while in many others the target group is low-income working households. The smaller the sector the more likely it is to concentrate on housing the most deprived; in more universalist systems, social housing tends to account for at least $20 \%$ of dwellings. In each country, the politics around social housing are conditioned by the size of the social sector, and its historic raison d'être. In Austria, for example, social housing is seen as a sustainable tenure that should be nurtured. In France, the Netherlands and Denmark, social housing is seen as mainstream. Germany recently formally redefined the target group for social housing. Previously social housing was meant for 'a wide realm of society', but under 2009 legislation it is aimed at those "who could not otherwise acquire adequate housing on the markets' (Droste and Knorr-Siedow, 2011). In many countries, the growth of owner-occupation has reduced social mix and social housing is increasingly seen as an inferior good. This is exacerbated by concerns about the concentration of crime and anti-social behaviour on social housing estates.

Table 8. Demographics of social housing

\begin{tabular}{|c|c|c|}
\hline & Age/household type & Income \\
\hline Austria & $\begin{array}{l}\text { Young families on new estates; older } \\
\text { people/singles on older estates }\end{array}$ & $\begin{array}{l}\text { Municipal housing: working } \\
\text { class/disadvantaged. Housing } \\
\text { associations: middle class }\end{array}$ \\
\hline Denmark & $\begin{array}{l}\text { Children and young people; } \\
\text { households with one adult }\end{array}$ & $\begin{array}{l}\text { Low-income and households } \\
\text { receiving transfers }\end{array}$ \\
\hline England & $\begin{array}{l}\text { Young and old; single parents, single } \\
\text { persons }\end{array}$ & $\begin{array}{l}\text { Low incomes }-<\text { half owner-occupier } \\
\text { income }\end{array}$ \\
\hline France & $\begin{array}{l}\text { Single-parent families and couples } \\
\text { with children }\end{array}$ & $\begin{array}{l}\text { Average household income } 74 \% \text { of } \\
\text { national average }\end{array}$ \\
\hline Germany & Older people & Lower income \\
\hline Hungary & & Low income and social status \\
\hline Ireland & $\begin{array}{l}\text { Single-parent families and couples } \\
\text { with children }\end{array}$ & $\begin{array}{l}62 \% \text { have incomes }<60 \% \text { of median } \\
\text { (vs } 22 \% \text { overall) }\end{array}$ \\
\hline Netherlands & Older/smaller than average & Lower than average and falling \\
\hline Sweden & Single parents, elderly single & Lower than average \\
\hline
\end{tabular}

Source: Whitehead and Scanlon (2007).

In many countries, though not all, social housing accommodates the vulnerable and those in most extreme housing need (those eligible for 'very social' housing in France). This may be provided by different types of landlord - quite often the municipality but also charities concentrating on specific groups. Historically, housing for very vulnerable groups such as ex-psychiatric patients, ex-addicts and female victims of domestic violence was often funded and provided separately from mainstream social housing, and there is still a distinction in many countries between responsibility for homelessness in general and provision for special groups who need additional care.

\section{Conclusions and future trends}

Comparative analysis suggests that there are some important general trends across Europe but also certain obvious differences. First, in almost all Northern European countries there is less emphasis on the 
provision of traditional social rented housing and more on providing a range of affordable tenures. There has also been a major shift away from special circuits of finance for social housing to the use of private finance and even private equity. The financial crisis has to some extent reversed these trends, at least temporarily, because public investment in housing has been seen as a useful stimulus, often involving public land and therefore lower financing requirements.

Second, there is a general shift away from subsidising supply and towards income-related support for tenants. This often entails raising rents as well as increasing borrowing against the value of the existing housing stock.

Third, there is a trend towards housing lower-income and more vulnerable households in the social sector. This was in part because of falling demand from higher-income households but more because, until recently, worsening affordability excluded low-income households from market housing. In addition, EU rulings restricting state aid to housing for middle-income households have increased the emphasis on housing the poor.

A fourth important trend is the increasing emphasis on improvement and regeneration of existing post-war housing to bring the stock up to date and redevelop areas where employment has declined. Social housing providers are often major partners in the delivery of mixed-use and mixed-tenure schemes.

A particular issue in France is the legacy of the past, in the form of large mono-tenure estates. Given the available stock, a move towards allowing only the poorest and most vulnerable people to live in social housing will inherently lead to greater concentrations of poverty and segregation in these estates. This is a problem identified across much of Northern Europe - but it is of particular relevance in France because of the nature and location of the poorer-quality social housing stock. 


\section{Bibliography}

Agence nationale de l'Habitat (2010), Les avantages fiscaux en faveur des logements du parc privé: législation applicable aux revenues de 2009, ANAH, Paris.

Ball, J. (2008), "Property, altruism and welfare: how national legal conceptions affect allocation of social housing to the disadvantaged", in K. Scanlon and C. Whitehead (eds.), "Social Housing in Europe II: A Review of Policies and Outcomes", II: 63-81, London School of Economics, London.

Banks, D. and C. Whitehead (2010), “Cross Tenure Rents and Affordability, 2008/09, Update”, University of Cambridge, Dataspring, Cambridge.

Crook, A.D.H. and C.M.E. Whitehead (2002), "Social housing and planning gain: is this an appropriate way of providing affordable housing?", Environment and Planning A, Vol. 34, 1259-1274.

Crook, A.D.H., J. Currie, A. Jackson, S. Monk, S. Rowley, K. Smith and C.M.E. Whitehead (2002), "Planning Gain and affordable housing: Making it count", Joseph Rowntree Foundation, York.

Czischke, D. and A. Pittini (2007), "Housing Europe 2007: Review of Social, Co-operative and Public Housing in the 27 EU Member States", CECODHAS, Brussels.

Department of Communities and Local Government (2006), Planning Policy Statement 3: Housing, Department of Communities and Local Government, London.

Desai, M., D. Dharmapala and M. Singhal (2009), "Tax Incentives for Affordable Housing: The Low-Income Housing Tax Credit", in Tax Policy and the Economy, National Bureau of Economic Research, Vol. 24, Cambridge, Massachusetts.

Driant, J.-C. (2011), "Le logement social en France entre inertie et mutations. Un état des lieux du 'système HLM' au seuil des annees 2010", in N. Houard (ed.), Loger l'Europe: Le logement social dans tous ses Etats, Paris: forthcoming.

Droste, C. and T. Knorr-Siedow (2011), "Social Housing in Germany - Changing Modes for a Changing Society", in N. Houard (ed.), Loger l'Europe: Le logement social dans tous ses états, Paris: forthcoming.

Elsinga, M. and G. van Bortel (2011, forthcoming), « The future of social housing in the Netherlands », in N. Houard (ed.), Loger l'Europe: Le logement social dans tous ses Etats, Paris: forthcoming.

Fitzpatrick, S. and M. Stephens (2007), "An International Review of Homelessness and Social Housing Policy", DCLG, London.

Fitzpatrick, S. and M. Stephens (eds.) (2008), “The Future of Social Housing”. Shelter, London.

Gibb, K. (2002), "Trends and Change in Social Housing Finance and Provision within the European Union", Housing Studies 17:2, 325-336. 
Hoekstra, J, I. Heras Saizarbitoria and A, Etxezarreta Etxarri (2010), "Recent changes in Spanish housing policies: subsidized owner-occupancy dwellings as a new tenure sector?", Journal of Housing and the Built Environment 25:125-138.

Holmans, A., K. Scanlon and C. Whitehead, J. Shilling and J. Hills (2002), "Policy Options to Promote Affordable Housing", Cambridge Centre for Housing and Planning Research, Cambridge.

Laferrère, A. and D. Le Blanc (2007), "Housing Policy: Low-Income Households in France", in (R.J. Arnott and D.P. McMillen (eds.), "A Companion to Urban Economics”, Blackwell Publishing Ltd, Oxford, UK.

Levy-Vroelant, C. and C. Tutin (eds.) (2010), Le logement social en Europe au debut du XXI siecle, PUR-editions, Presse Universitaires de Rennes, Rennes.

Levy-Vroelant, C. and C. Tutin (2007), "Social Housing in France", in C. Whitehead and K. Scanlon (eds.), "Social Housing in Europe”, I: 70-89, London School of Economics, London.

McClure, K. (2000), "The Low-Income Housing Tax Credit as an Aid to Housing Finance: How Well Has It Worked?”, Housing Policy Debate, Vol. 11, Issue 1, 91-114.

Monk, S. and C. Whitehead (2010), “Affordable Housing and Intermediate Housing Tenures”, Blackwell, Oxford.

Oxley, M. (2010), "Promoting investment in private rented housing supply: International policy comparisons", Department for Communities and Local Government, London.

Oxley, M. (2009), "Financing Affordable Social Housing in Europe”, UN-HABITAT, Nairobi.

Priemus, H. (2010), "Housing Finance Reform in the Making: The Case of the Netherlands", Housing Studies, Vol. 25, No. 5.

Scanlon, K. (2010), "International experience", in S. Monk and C. Whitehead (eds.), "Making Housing More Affordable: The role of intermediate tenures", Blackwell, Oxford.

Schaefer, J.P. (2003), "Financing Social Housing in France”, Housing Finance International, 1 June 2003, 27-34.

Stephens, M., N. Burns and L. McKay (2002), "Social market or safety net British social rented housing in a European context", Policy Press, Bristol.

Stephens, M., Elsinga M and Knorr-Siedow T (2008), 'The privatisation of social housing: Three different pathways' in K. Scanlon and C. Whitehead (eds.), "Social Housing in Europe II", London School of Economics, London.

Whitehead, C. and K. Scanlon (2007), "Social Housing in Europe", in C. Whitehead and K. Scanlon (eds.), "Social Housing in Europe II", London School of Economics, London.

Whitehead, C. (2008), "Financing Social Housing”, in K. Scanlon and C. Whitehead (eds.), "Social Housing in Europe II", London School of Economics, London. 


\section{WORKING PAPERS}

The full series of Economics Department Working Papers can be consulted at www.oecd.org/eco/workingpapers/

861. Making the French housing market work better

(May 2011) by Hervé Boulhol

860. Surveillance by international institutions: lessons from the global financial and economic crisis (April 2011) by Kumiharu Shigehara and Paul Atkinson

859. France's environmental policies: internalising global and local externalities (April 2011) by Balázs Égert

858. Bringing French public debt down: the options for fiscal consolidation (April 2011) by Balázs Égert

857. Policy frameworks in the post-crisis environment (April 2011) by Nigel Pain and Oliver Röhn

856. Global imbalances, exchange rate pegs and capital flows: a closer look (April 2011) by Paul van den Noord

855 Interest rate pass-through during the global financial crisis: the case of Sweden (April 2011) by Niels-Jakob Harbo Hansen and Peter Welz

854 What drives inflation in the major OECD Economies (April 2011) by Diego Moccero, Shingo Watanabe and Boris Cournède

853 Mitigation potential of removing fossil fuel subsidies: A general equilibrium assessment (April 2011) by J.M. Burniaux and J. Chateau

852 Enhancing labour utilisation in a socially inclusive society in Australia (April 2011) by Vassiliki Koutsogeorgopoulou

851 Meeting infrastructure needs in Australia (March 2011) by Claude Giorno

850 Restoring fiscal sustainability in Spain (March 2011) by Pierre Beynet, Andrés Fuentes, Robert Gillingham and Robert Hagemann

849. Drivers of homeownership rates in selected OECD countries (March 2011) by Dan Andrews and Aida Caldera Sánchez

848. How efficient are banks in Hungary?

(February 2011) by Margit Molnár and Dániel Holló

847. Strengthening the macroeconomic policy framework in South Africa (February 2011) by Tatiana Lysenko and Geoff Barnard

846. To move or not to move: what drives residential mobility rates in the OECD? (February 2011) by Aida Caldera Sánchez and Dan Andrews 
ECO/WKP(2011)31

845. Reforming the labour market in Spain

(February 2011) by Anita Wölfl and Juan S. Mora-Sanguinetti

844. Macroeconomic Impact of Basel III

(February 2011) by Patrick Slovik and Boris Cournède

843. The policy and institutional drivers of economic growth across OECD and non-OECD economies: new evidence from growth regressions

by Romain Bouis, Romain Duval, and Fabrice Murtin

842. Limiting Long-Term Unemployment and Non-Participation in Sweden

(February 2011) by Niels-Jakob Harbo Hansen

841. Enhancing the cost-effectiveness of climate change mitigation policies in Sweden

(February 2011) by Stéphanie Jamet

840. Policies towards a sustainable use of water in Spain

(February 2011) by Andrés Fuentes

839. Increasing public sector efficiency in Slovakia

(January 2011) by Felix Hüfner

838. Raising education outcomes in Switzerland

(January 2011) by Andrés Fuentes

837. The Price Responsiveness of Housing Supply in OECD Countries

(January 2011) by Aida Caldera Sánchez and Åsa Johansson

836. Housing markets and structural policies in OECD countries

(January 2011) by Dan Andrews, Aida Caldera Sánchez and Åsa Johansson

835. Raising potential growth after the crisis: A quantitative assessment of the potential gains from various structural reforms in the OECD area and beyond

(January 2011) by Romain Bouis and Romain Duval

834. The GDP impact of reform: a simple simulation framework

(January 2011) by Sebastian Barnes, Romain Bouis, Philippe Briard, Sean Dougherty and Mehmet

Eris

833. Improving the flexibility of the Dutch housing market to enhance labour mobility

(January 2011) by Jens Høj

832. Making the Dutch pension system less vulnerable to financial crises

(January 2011) by Jens Høj

831. Real house prices in OECD countries: the role of demand shocks and structural policy factors (December 2010) by Dan Andrews

830. International financial integration and the external positions of euro area countries (December 2010) by Philip R. Lane 